\title{
Proregion of Acanthoscelides obtectus cysteine proteinase: A novel peptide with enhanced selectivity toward endogenous enzymes
}

\author{
F.B. Silva ${ }^{a, b}$, A.C.S. Monteiro ${ }^{a}$, R.P. Del Sarto ${ }^{a, b}$, B.M. Marra ${ }^{a, b}$, S.C. Dias ${ }^{a, b, c}$, \\ E.L.Z. Figueira ${ }^{a}$, G.R. Oliveira ${ }^{a, b}$, T.L. Roch $a^{a}$, D.S.L. Souza ${ }^{b}$, M.C.M. da Silva $^{a}$, \\ O.L. Franco ${ }^{c, d}$, M.F. Grossi-de-Sa ${ }^{a, c, *}$

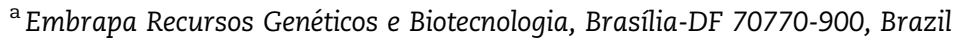 \\ ${ }^{\mathrm{b}}$ Universidade de Brasília, Brasilia-DF 70910-900, Brazil \\ ${ }^{c}$ Centro de Análises Proteômicas e Bioquímica, Pós-Graduação em Ciências Genômicas e Biotecnologia, UCB, Brasília-DF 70790-160, Brazil \\ ${ }^{\mathrm{d}}$ Departamento de Biologia, Universidade Federal de Juiz de Fora, MG, Brazil
}

A R T I C L E I N F O

Article history:

Received 23 January 2007

Received in revised form

21 March 2007

Accepted 22 March 2007

Published on line 31 March 2007

Keywords:

Acanthoscelides obtectus

Cysteine proteinase

Propeptide

Plant defense

\begin{abstract}
A B S T R A C T
Acanthoscelides obtectus is a devastating storage insect pest capable of causing severe bean crop losses. In order to maintain their own development, insect pest larvae feed continuously, synthesizing efficient digestive enzymes. Among them, cysteine proteinases (CPs) are commonly produced as inactive precursors (procysteines), requiring a cleavage of the peptide proregion to become active. The proregion fits tightly into the active site of procysteines, efficiently preventing their activity. In this report, a CP cDNA (cpao) was isolated from A. obtectus midgut larvae. In silico studies indicated that the complete CP sequence contains a hydrophobic signal peptide, a prodomain and a conserved catalytic region. Moreover, the encoding cDNA contains $963 \mathrm{bp}$ translating into a 321 residue protein, CPAo, which was expressed in E. coli, fused with thioredoxin. Enzymatic assays using the recombinant protein revealed that the enzyme was catalytically active, being able to cleave the synthetic substrate Z-Phe-Arg-7-AMC. Additionally, this report also focuses the cpao propeptide (PCPAo) subcloning and expression. The expressed propeptide efficiently inhibited CPAo, as well as digestive CP of other bean bruchids. Little or no activity was found against proteolytic enzymes of two other coleopterans: Rhyzopertha dominica and Anthonomus grandis. The data reported here indicate the possibility of endogenous propeptides as a novel strategy on bruchids control, which could be applicable to bean improvement programs.
\end{abstract}

(c) 2007 Published by Elsevier Inc.

\section{Introduction}

Plant tissues are frequently attacked by insect pests and pathogens. This predation process can lead to severe economic loss [1]. Two species of bruchids, Acanthoscelides obtectus and Zabrotes subfasciatus, are known to cause intense damage to the common bean grains Phaseolus vulgaris [7,21]. The digestion process of bean bruchids is essentially based on

\footnotetext{
* Corresponding author. Tel.: +55 613448 4705; fax: +55 6133403624 .

E-mail address: fatimasa@cenargen.embrapa.br (M.F. Grossi-de-Sa).

Abbreviations: AMC, amidomethylcoumarin; CP, cysteine proteinase; CPAo, cysteine proteinase from Acanthoscelides obtectus; DTT, dithiotreitol; DMSO, dymethyl sulfoxide; E-64, trans-epoxysuccinyl-L-leucylamide-(4-guanidino)butane; PCPAo, propeptide of cysteine proteinase from A. obtectus 0196-9781/\$ - see front matter (C) 2007 Published by Elsevier Inc. doi:10.1016/j.peptides.2007.03.020
} 
proteolytic enzyme activities, which include mainly serine and cysteine proteinases (CPs). The CPs are strictly involved in intra- and extra-cellular protein degradation, playing a key role in the synthesis of free essential amino acids, which are utilized for insect growth and development $[1,6]$.

Due to the importance of cysteine proteinases to bean weevils' digestion mechanisms, special attention has been given to this specific enzyme. Catalytic domains of papainlike CPs share a very similar three-dimensional structure and possess a well-conserved catalytic site [19]. These enzymes are involved in a wide variety of biological processes, including housekeeping tasks within the endosomal/lysosomal system, specific functions in antigen presentation prohormone processing, as well in pathogen and insect pest predation [26]. For the potential involvement with insect pests and pathogen predation, a co-evolution process leads several organisms to synthesize several classes of compounds that are capable of reducing proteolytic activity. These compounds are known as proteinase inhibitors [20] and several reports have described high inhibitory activity of different proteinase inhibitors toward digestive enzymes, indicating their potential as biotechnological tools for insect pest control [12,22].

It was also shown that several peptides can inhibit proteolytic enzymes. Among them, the propeptides of cognate digestive proteinase enzymes have been described as extremely effective $[5,10]$. In the papain-like family, a single propeptide is synthesized to the inactive enzyme. This combo production inhibits cysteine proteinases, improving the control over proteolyses as revised by Yamamoto et al. [34]. Other studies indicate that CP propeptides are potent inhibitors of their cognate enzymes [30,32]. An enhanced selectivity to the proteinase subtype was identified, in which the cathepsin B proregion was unable to inhibit the cathepsin L subfamily, and vice-versa [33]. Recently, the use of cysteine proteinase propeptides was explored as an anti-nematode effector, in which the product of the prodomain of Heterodera glycines cysteine proteinase exhibited high in vitro inhibitory activity against its cognate enzyme and to other related nematode proteinases, but did not inhibit cysteine proteinases of insect pest species [27].

On the other hand, CPs could be distinguished according to their proregions. By using this parameter, CPs could be divided into to two different groups: cathepsin L-like enzymes possessing proregions greater than 90 amino acids residue length, and cathepsin B-like enzymes are formed by a smaller proregion, with around 62 amino acid residues [4,17,31]. CPs from the cathepsin L-like family present a globular N-termini domain comprising two intersecting $\alpha$-helices and a $\beta 1$ strand. An active binding cleft segment and a highly flexible Cterminal segment follow this domain [2]. Both helices are not directly involved in the active side cleft occlusion, but strongly influence the propeptide affinity to the catalytic domains [14]. The inhibitory mechanism of the prodomain comprises the substrate obstruction to the active site, in which the proregion follows the groove in the opposite direction of substrate, resulting in an inappropriate positioning of the peptide bond for hydrolysis [11].

Aiming to assess the potential use of proteinase proregion in plant biotechnology as have been proposed $[27,30,32]$, this report describes the molecular cloning and expression of a complete cDNA sequence encoding a cathepsin L-like enzyme of A. obtectus and shows the efficiency of the N-terminal proregion domain product in inhibit bruchid cysteine enzymes, indicating its possible application in the control of bean weevils.

\section{Material and methods}

\section{1. cDNA cloning of A. obtectus cysteine-like proteinase}

Total RNA was isolated from homogenized A. obtectus Say (Coleoptera: Bruchidae) midgut larvae following the RNeasy Mini Handbook (Qiagen ${ }^{\mathbb{}}$ ) techniques. For the reverse transcription of A. obtectus, cDNA was done using oligo $d(t)$-anchor primer and AMV-RT (Boehringer Mannheim ${ }^{\mathbb{R}}$ ) according to the manufacturer's instructions, using $4 \mu \mathrm{g}$ of total RNA. RT-PCR was performed using two degenerate primers P1 (5'TGCGGVTCVTGYTGG-3') and P2 (5'-ACCRCCRTYGCARCC-3'), based on consensus sequences found in a number of CPs with an annealing temperature of $42^{\circ} \mathrm{C}$. To obtain the complete cDNA sequences, the $5^{\prime}$ and $3^{\prime}$ ends were amplified using a $5^{\prime} / 3^{\prime}$ RACE kit (Boehringer Mannheim ${ }^{\circledR}$ ) according to the manufacturer's instructions. The $5^{\prime}$ RACE was performed using primers P3 (5'AAGGTTCTCGTATTT-3'), P4 (5'-AGATCAACGTTTTATT-3') and P5 (5'-AACAGCACTGAAAGC-3'). 3' RACE-PCR was carried out using primers $P 6$ (5'-CCCGTGTCAGTGGGGCAACTA-3') and P7 (5'-CCCATGAAGGGTCTCGCTATA-3'). The complete gene was amplified with primers P8 (5'-GGGGAATTCATGAAGGGTCTCGCT) and P9 (5'-AAGGATCCGCTCTACAAAATAGGA-3') and cloned into the pGEM-T Easy Vector (Promega ${ }^{\circledR}$ ). Several clones were sequenced in both strands with an ABI Prism 3700 DNA Analyzer (PE Biosystems ${ }^{\mathbb{R}}$ ). Computer analysis of the DNA and derived amino acid sequences were done using the GCG package (Genetics Computer Group, Inc.), bioinformatics resources of the NCBI homepage (http://www.ncbi.nlm.nih.gov) and the EBI website (http://www.ebi.ac.uk/).

\subsection{Expression and purification of PCPAo and CPAo}

Coding region of A. obtectus cysteine proteinase (CPAo) and its proregion (PCPAo) were subcloned into the pET102D TOPO (Invitrogen ${ }^{\mathbb{R}}$ ) and pQE40 (Qiagen ${ }^{\mathbb{R}}$ ) vectors, respectively. E. coli-competent cells were heat shock transformed using CPAo (strain BL21 DE3) and PCPAo (strain M15). The expression of both recombinant proteins were induced with $2.0 \mathrm{mM}$ and $0.5 \mathrm{mM}$ isopropil-1-thiol- $\beta$-D-galactopyranoside (IPTG), for $3 \mathrm{~h}$. Recombinant protein solubility was evaluated under different temperatures and salt concentrations. E. coli pellet cells were incubated for $1 \mathrm{~h}$ at $25^{\circ} \mathrm{C}$ in buffer A $(8.0 \mathrm{M}$ urea; $0.1 \mathrm{M}$ $\mathrm{NaH}_{2} \mathrm{PO}_{4} ; 0.01 \mathrm{M}$ Tris- $\left.\mathrm{HCl}\right)$ at $\mathrm{pH} 8.0$ and continuous shaking. The lysate was centrifuged at $10,000 \times g$ for $20 \mathrm{~min}$ and the supernatant was loaded onto an affinity Ni-NTA (Qiagen ${ }^{\circledR}$ ) column. Unbound proteins were removed with five sequential washes in buffer A at pH 6.3, then the recombinant protein was eluted from resin using buffer $\mathrm{A}$ at $\mathrm{pH}$ 4.5. CPAo was refolded by slow drop-wise dilution ( $\cong 20 \times$ dilution), stirring in the refolding buffer (50 mM Tris- $\mathrm{HCl}, \mathrm{pH}$ 8.0; 5 mM EDTA; $10 \mathrm{mM}$ reduced glutathione; $1 \mathrm{mM}$ oxidized glutathione) and then 
stirring overnight at $4{ }^{\circ} \mathrm{C}$ [10]. The renatured CPAo (10 ng per assay) was used for the proteolytic assays. The purified PCPAo was dialyzed against buffer $50 \mathrm{mM}$ Tris- $\mathrm{HCl}$ at $\mathrm{pH}$ 8.0, followed by thrombin cleavage $(40 \mathrm{~h})$ for removal of the $\mathrm{N}$-termini leader. Digested PCPAo was used in the proteolytic assays. The recombinant PCPAo ( $\approx 50-100 \mu \mathrm{g})$ was analyzed and excised from $12 \%$ SDS-PAGE [15] and used for the production of an antiserum in mice (BALB/c, female) as previously described by Grossi-de-Sa et al. [9].

\subsection{Proteolytic assays}

Midguts from fourth-instar Coleoptera larvae of A. obtectus, Z. subfasciatus, C. maculatus, A. grandis, and R. dominica were dissected into ice-cold $0.1 \mathrm{M}$ Tris- $\mathrm{HCl}, \mathrm{pH}$ 8.0. Freshly dissected midguts were homogenized and centrifuged at
$4,000 \times g$ for $20 \mathrm{~min}$ at $4{ }^{\circ} \mathrm{C}$, to remove gut walls and cellular debris. The supernatant (at a standard protein concentration of $12 \mathrm{ng}$ ) was used to measure the CP proteolytic activity and to analyze the inhibitory effects of PCPAo against CPs. Proteolytic inhibitory activities were tested against all enzymes described above using $10 \mu \mathrm{M}$ of fluorogenic peptide Z-Phe-Arg-7-MCA (Sigma Co. ${ }^{\circledR}$ ). Assays were performed in $25 \mathrm{mM}$ Tris- $\mathrm{HCl}, \mathrm{pH}$ 6.0, according to Solomon et al. [28]. The reaction was stopped with $1.9 \mathrm{ml}$ of $0.2 \mathrm{M} \mathrm{Na}_{2} \mathrm{CO}_{3}$. The endpoint reaction was measured after $30 \mathrm{~min}$ in a DyNA Quant 500 fluorescence reader (Amersham Pharmacia ${ }^{\circledR}$ ), with excitation at $365 \mathrm{~nm}$ and emission at $460 \mathrm{~nm}$. In inhibitory assays, the recombinant CPAo was pre-incubated with the recombinant PCPAo (67 ng) or the synthetic inhibitor E-64 [trans-epoxysuccinyl-L-leucylamide-(4-guanidino) butane] $(10 \mu \mathrm{M})$, for $15 \mathrm{~min}$ at $37^{\circ} \mathrm{C}$. Antiserum was used as a second positive control in order to

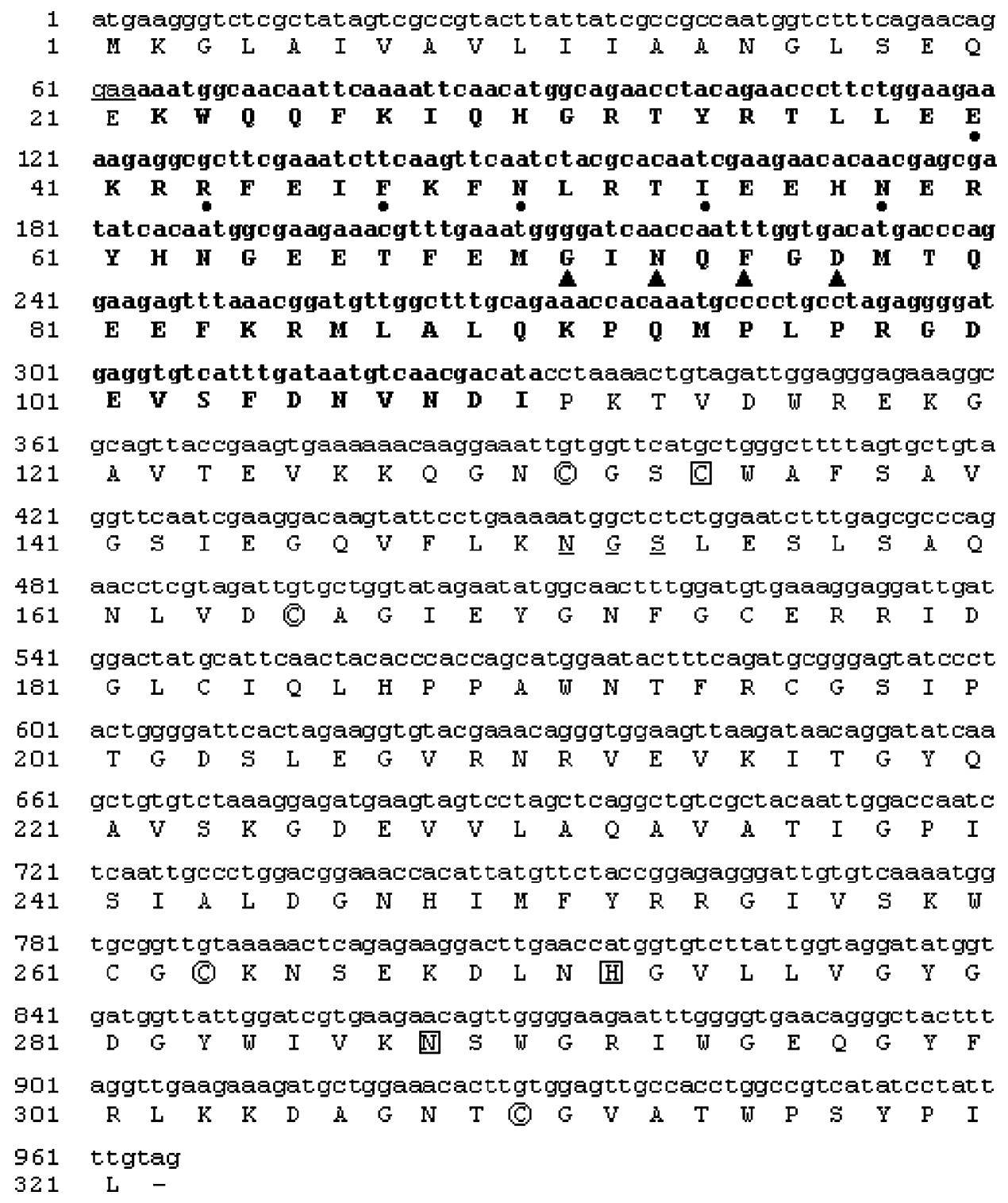

Fig. 1 - Nucleotide and deduced amino acid sequence of the cpao cDNA. The propeptide sequence is indicated in bold. The three residues involved in the active site (Cys, His, Asn) are boxed. Dots indicate the residues of the interspersed ERFNIN motif and triangles indicate residues of the interspersed GNFD motif. Underlines indicate potential N-glycosylation site in the sequence. Circles indicate conserved cysteine residues that could form disulfide bridges. Sequence data have been submitted to GenBank under accession number AY345219.1. 
abolish PCPAo inhibitory activity. The inhibitory activities were calculated using the fluorescence reduction. The inhibitory activities were directly compared to free MCA produced by cysteine-like enzymes. One relative unit corresponds to $0.5 \mathrm{mM}$ of free MCA produced for $30 \mu \mathrm{g} \mathrm{ml}^{-1}$
1 of proteinases utilized, after $30 \mathrm{~min}$ of reaction. The blank fluorescence readings (minus substrate) were subtracted. Assays were carried out in triplicate, with variability in endpoint fluorescence values not exceeding $10 \%$.

\begin{abstract}
AY345219.1 ARQ 11970.1 CAD33266.1 BAA 2 4442.1 AAL 34984.1 NP 001903 AAG 17127.1 AAR02406.1 AHP 94048.2 P05994
\end{abstract}

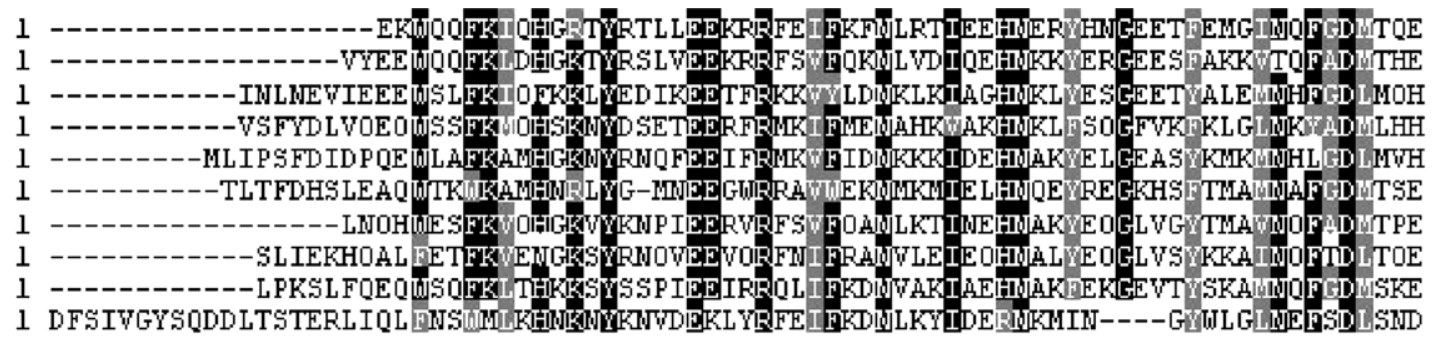

Propeptide Mature protein

AY345219.1 AA011970.1

CAD 33266.1 BAA2 24442.1 AHL 34984.1 NP 001903

AAG 17127.1 AAR02406. 1 ARP 94048.2 P05994

AV345219.1 ARO11970.1 CAD 33266.1 BAम224442.1 AnL 34984 . I NP 001903 AAG 17127.1 ARR02406.1 AAP94048.2 P05994

AY345219.1 AR011970.1 CAD33266.1 BA겨 24442. 1 AAL34984. 1 NP 001903 AAG 17127.1 AAR02406.1 AHP 4048.2 P05994

AY 345219.1 ARQ11970.1 CAD33266.1 BA그 24442. 1 ARL 34984.1 NP 001903 AAG 17127.1 ARR02406.1 ARP94048.2 P05994

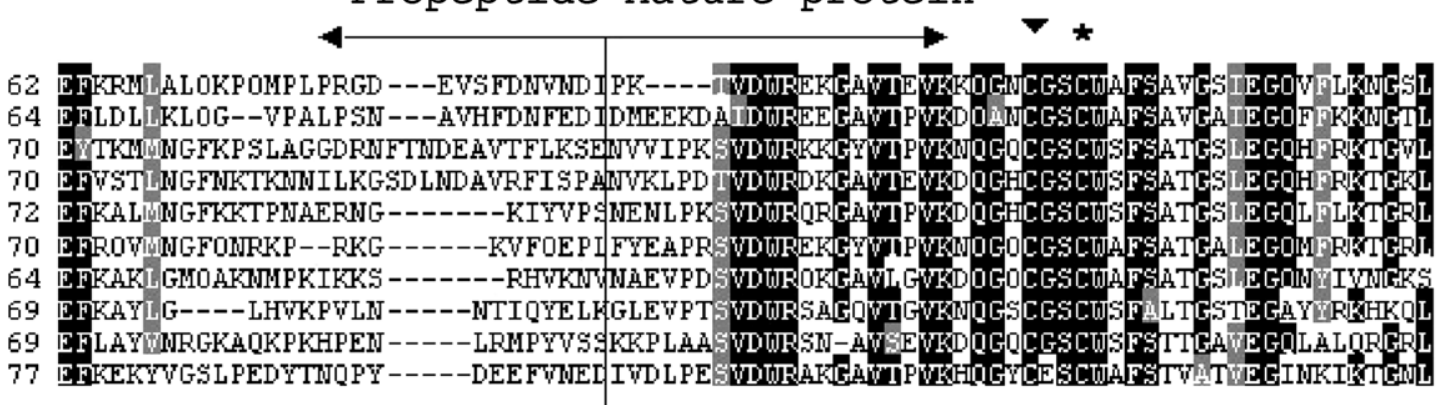

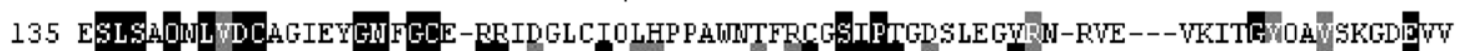
139 WSLSA 150 VSLSEOWLIDCS-RKYGWWGCE-GGLDDLAFKYIKSNKGLDIEKSYPYEMEDDKCRY-NPENSGATDKG WWD IPEGDED Ä 150 WSLSEONL WDCS-GRYGWNGCN-GEL WDNAFRYIKDNGGIDTIRSYPYLAEDEKCHY-KAONSGATDKG PWD IEEANEDD

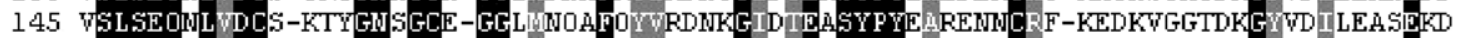
142 ISLSEOWL WDCS-GPOGNEGCN-GELWDYAFOYODNGGLDSEESYPYE MTEESCKY-NPKYSWANDTGWWDIPK-QEVA

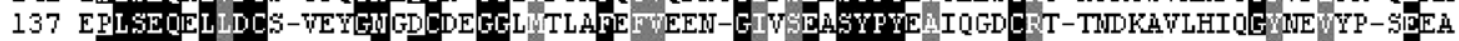
140 WSLSEDOLWDS-TSI-WYGCN-GGFLDATFPYIEQY-GLONESSYPYTGVDGSCKY-DSSKWTKISNYVSLH-GSESK

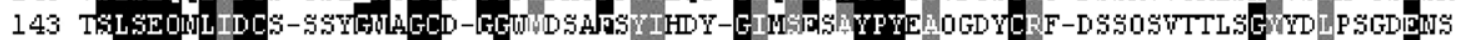

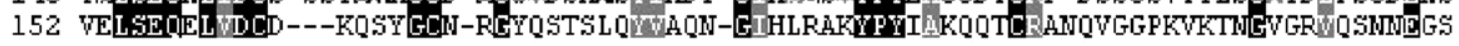

$\star$

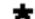

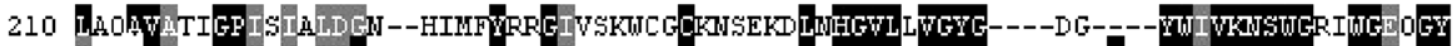

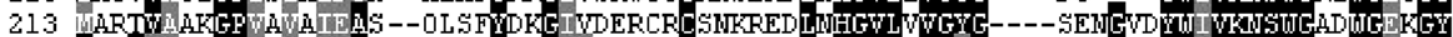

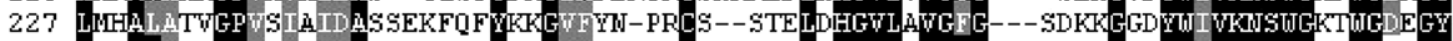

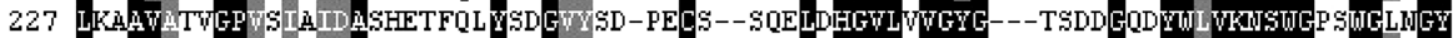
222 LOSA W

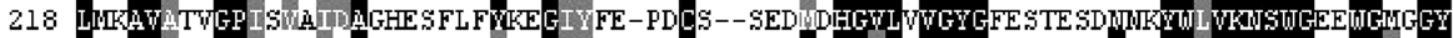

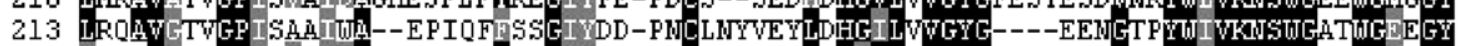

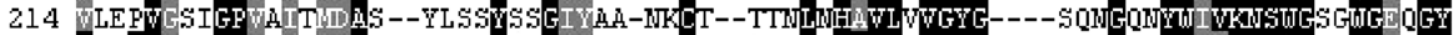

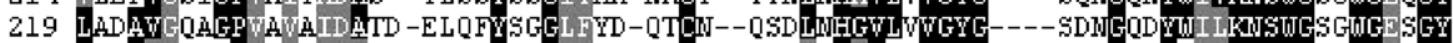

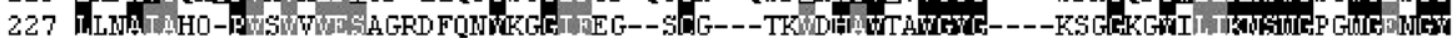
$\nabla$

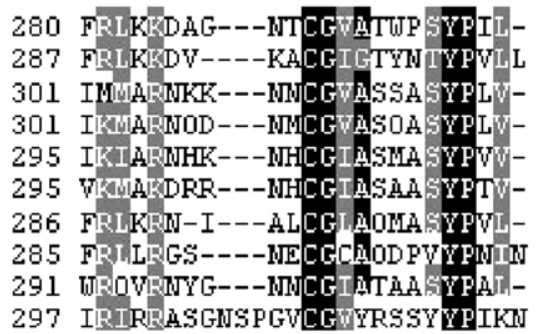

Fig. 2 - Sequence alignment of cathepsin L-like pro-mature sequence from several species. Pre-regions were detected by SignalP but omitted in the alignment. Sequences sources are: A. obtectus CPAo (AY345219.1), C. maculatus (AAQ11970.1), A. gossyppi (CAD33266.1), S. zeamais (BAA24442.1), R. prolixus (AAL34984.1), H. sapiens (NP_001903), D. virgifera virgifera (AAG17127.1), A. grandis (AAR 02406.1), T. mollitor (AAP94048.2), and papain from C. papaya (P05994). Amino acid residues of the catalytic triad are marked by an asterisk. Arrows indicate conserved cysteine residues that could form disulfide bridges and the line divides pro- and mature regions. 


\section{Results and discussion}

\subsection{Molecular cloning of CPAo}

The full-length cpao cDNA (963 bp) has an open reading frame of 321 amino acid residues length (Fig. 1). Multiple alignment analysis of the predicted protein sequence shows high homology to cathepsins L-like proteinases from several sources as visualized in Fig. 2. As other cathepsins from papain superfamily, CPAo is synthesized as prepro-proteinase (Fig. 1), and a direct comparison to other cathepsins indicated that Ile $_{110}$ is the probable pro-sequence cleavage site showing a pro-sequence of 89 residues followed by a mature protein composed by 211 residues (Fig. 1). The molecular mass of deduced pro-protein $(34.0 \mathrm{kDa})$ was determined by the Protein Machine software available at the Expasy site (http://us.expasy.org/tools/). Further, primary structure analysis strictly showed homology of CPAo to other mature cysteine-like proteinases. The structure of cloned CPAo was proposed by threading analyses (BioInfo Meta Server) revealing extreme similarities to egg white cystatin, which have their structure solved by X-ray diffraction (data not shown) [3]. This model revealed a wedge shape composed of a five-stranded antiparallel $\beta$-pleated sheet wrapped around a central long $\alpha$-helix folded into a wedge, with the partially flexible $\mathrm{N}$-terminal segment and the first and a second $\beta$-hairpin loop forming a molecular edge [3]. Moreover, detailed information is focused on the catalytic triad residues $\left(\mathrm{Cys}_{25}\right.$, $\mathrm{His}_{159}$ and $\mathrm{Asn}_{175}$, denoted by box in Fig. 1) that were conserved in papain-like proteinase family. In addition, the CPAo an active site contains four conserved half-cysteines probably involved in disulfide bound formation ( $\mathrm{Cys}_{131}-\mathrm{Cys}_{165}$ and $\mathrm{Cys}_{263}-\mathrm{Cys}_{310}$ ) (Fig. 1). Therefore, the propeptide showed homology to interspersed ERFNIN motif (dots in Fig. 1) present in cathepsins L, H, and S and totally absent in cathepsin B-like enzymes [13]. The other conserved motif GNFD that is limited to the papain superfamily [19] is also present in propeptides of CPAo, which are strictly involved in contact to the enzyme surface (triangles in Fig. 1). According to Czaplewski et al. [6], both motifs and the prosegment-binding loop (PBL) of enzyme core $\left(\mathrm{H}_{140}-\mathrm{D}_{155}\right.$ in cathepsin $\mathrm{L}$ ) are essential for the $\mathrm{N}$-termini folding into a conserved structural core and also to direct the propeptide fragment at opposite side of substrate into the binding site cleft. Experiments carried out with recombinant truncated propeptide of cathepsin $\mathrm{L}$ have demonstrated that two $\mathrm{N}$-terminal $\alpha$-helices are essential for propeptide binding, greatly contributing to stability $[33,8]$. In relation to homology searches using BLASTP, the deduced amino acid sequence of isolated cDNA clearly showed that CPAo belongs to the $\mathrm{C} 1$ peptidase papain superfamily as defined by Rawlings and Barrett [24]. Furthermore, CPAo showed high identity (50\%) to putative gut cathepsin L-like CP from C. maculatus (Fig. 2). Significant identities were also found to Diabrotica virgifera virgifera (Coleoptera) cathepsin L-like (44\%), human cathepsin L (43\%), cathepsins L-like of Sitophilus zeamais (Coleoptera), Tenebrio molitor (Diptera), and Rhodnius prolixus (Hemiptera) (41\%), cathepsins L-like of A. grandis (Coleptera) and Aphis gossypii (Hemiptera) (40\%) (Fig. 2). These data suggest a clear primary structure relation between insect cysteine proteinases. Similar studies were previously carried out with five different CPs synthesized by Paragonimus westermani adult

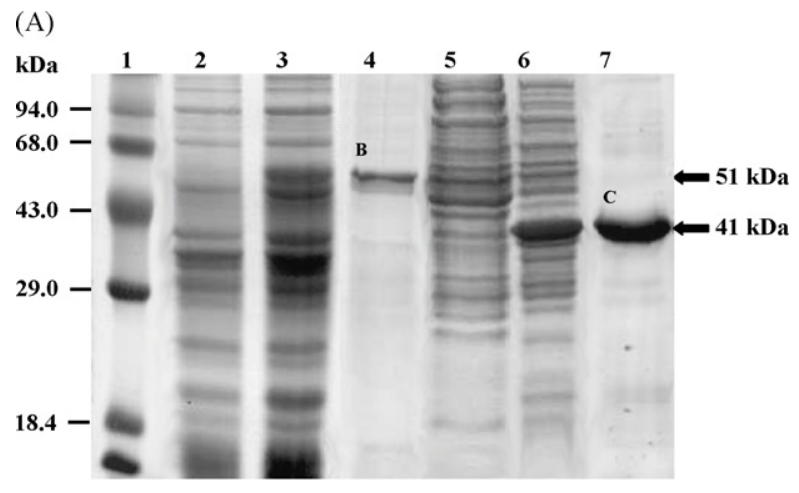

(B)

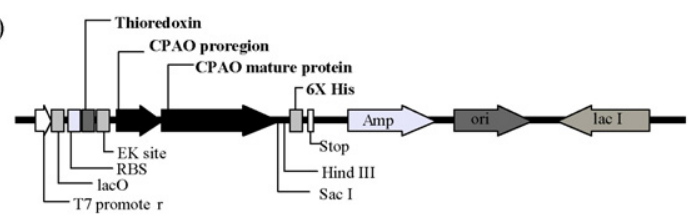

(C)

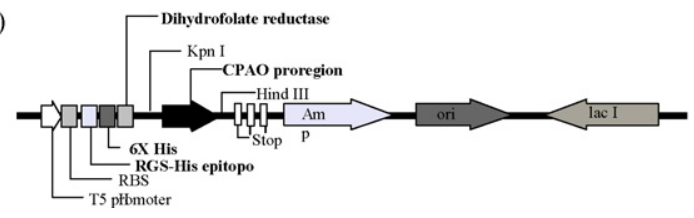

Fig. 3 - Expression and purification of recombinant mature CPAo (B in lane 4) and propeptide CPAo (C in lane 7) in E. coli system. The expression of the recombinant proteins was induced with IPTG for $3 \mathrm{~h}$ at $37^{\circ} \mathrm{C}$ and purified in affinity chromatography. The total protein extracts were analyzed by $12 \%$ SDS-PAGE and stained with Coomassie blue, showing the expression of mature form and propeptide (A). Mature form and propeptide. Lane 1, molecular weight markers; lane 2, non-induced extracts (CPAo); lane 3, induced extracts (CPAo); lane 4, purified recombinant CPAo; lane 5, non-induced extracts (PCPAO); lane 6, induced extracts (PCPAo); lane 7, purified recombinant PCPAo. The recombinant proteins are indicated with a black arrow. Constructions of CPAO (B) and PCPAo (C) vectors for expression in E. coli using the PET102D TOPO and PQE40 systems. Sequence encoding the mature form was amplified by PCR and cloned in frame with thioredoxin at the $5^{\prime}$ region and a His-tag tail at the $3^{\prime}$ region (B). Sequence encoding the propeptide region was amplified by PCR and cloned in frame with dihydrofolate reductase and a His-tag tail at the $5^{\prime}$ region $(\mathrm{C})$.

worms, which showed that insect cysteine proteinases could be grouped together [23].

\subsection{Expression and purification of recombinant proteins (PCPAo and CPAo)}

In order to study the effects of the PCPAo toward its cognate enzyme (CPAo), the propeptide, as well as the mature enzyme, were expressed in the E. coli system. For the PCPAo, the nucleotide sequence encoding the CPAo proregion was amplified by PCR using specific flanking primers and cloned in frame at its $5^{\prime}$ end with dihidrofolate reductase (DHFR) site 
in the $\mathrm{PQE} 40^{\circledR}$ vector (Fig. 3C). The sequence encoding mature protein (CPAo) was cloned in frame at its $5^{\prime}$ end with thioredoxin in the pET102D ${ }^{\circledR}$ TOPO (Fig. 3B). The fusion with DHFR/thioredoxin was chosen in both cases to increase solubility, stability, and avoid degradation of recombinant proteins. SDS-PAGE analysis of total protein extracts revealed a major band of $51.0 \mathrm{kDa}$. Apparently, this is the molecular mass for CPAo plus fusion protein (Fig. 3A, lane 3). Additionally, a molecular mass of $41.0 \mathrm{kDa}$ was observed for the propeptide plus fusion protein (PCPAo) (Fig. 3A, lane 6). No expressed protein band was found at uninduced cell extracts (Fig. 3A, lanes 2 and 5). Both recombinant proteins were detected in the insoluble cellular fraction (data not shown) and inclusion bodies were solubilized in $8.0 \mathrm{M}$ urea and further purified using affinity chromatography by using a Ni-NTA affinity column (Fig. 3A, lanes 4 and 7). A thrombin digestion process was utilized to purify recombinant fusion protein. At first, recombinant CPAo expressed in E. coli was inactive and the proteolytic activity was recovered by slow serial dilution in buffer containing glutathione oxidized/reduced. Several proteins have been renatured by this procedure, including enzymes and also proteinaceous inhibitors $[10,18]$.

\subsection{Proteolytic assays}

In vitro inhibitory fluorimetric assays showed that CPAo was totally inhibited by the PCPAo, as well by the CP-specific synthetic inhibitor E-64 (Fig. 4). Furthermore, previous incuba-

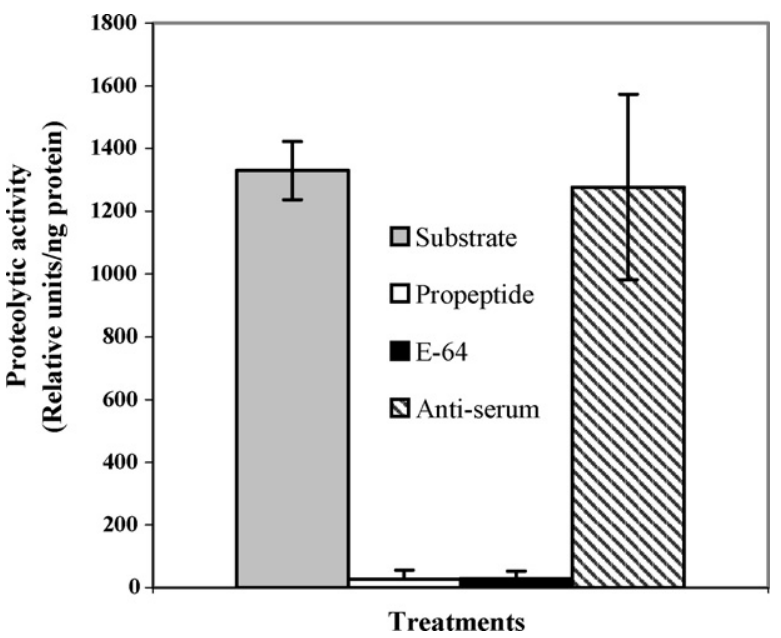

Fig. 4 - Inhibitory fluorimetric assay. Bars indicated the activity of CPAo (gray) and also the enzyme activity in the presence of PCPAo (white); E-64 (black) and specific antibody raised against PCPAo (hachured). The fluorimetric assays were performed in a DyNA Quant 500 fluorescence reader (Pharmacia-Biotech), using the Z-PheArg-AMC as substrate $(10 \mu \mathrm{M})$. The inhibitors were preincubated with the enzymes for $15 \mathrm{~min}$ at $37^{\circ} \mathrm{C}$, before the measurement of the remaining CP proteolytic activities. The reaction was performed with $2.5 \mathrm{mM}$ DTT, 5\% DMSO, $2.0 \mathrm{mM}$ EDTA and $0.1 \mathrm{M} \mathrm{Na}_{2} \mathrm{HPO}_{4}$ at $\mathrm{pH}$ 6.5. All determinations were based on assays with less than $2 \%$ of substrate hydrolysis. Data represent (mean \pm S.D.) from at least three different experiments.

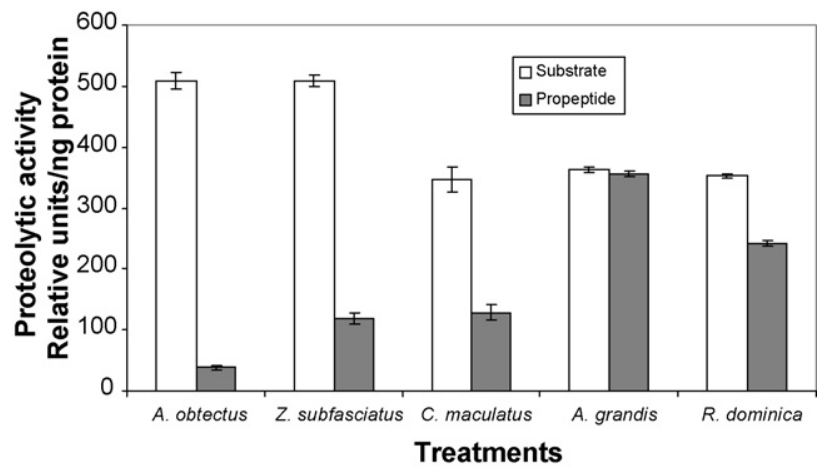

Fig. 5 - Recombinant PCPAo inhibitory activity against midgut crude soluble extracts from $A$. obtectus, $Z$. subfasciatus, C. maculatus, A. grandis, and R. dominica. The fluorimetric assays were performed as described before. Data represent (mean \pm S.D.) from at least three different experiments. Vertical bars represent standard deviation.

tion of PCPAo with polyclonal antibodies, raised against the propeptide, was able to abolish PCPAo inhibitory activity (Fig. 4). The prodomain specificities were also evaluated against several sources of digestive enzymes, which included A. obtectus, $Z$. subfasciatus, C. maculatus, A. grandis, and R. dominica (Fig. 5). PCPAo efficiently inhibited the CP proteolytic activity of bean bruchids extracts. By contrast, PCPAo produced low inhibitory activity against $R$. dominica CPs (32\%) and no activity was identified toward A. grandis CPs (Fig. 5). Similar data were obtained with $\mathrm{H}$. glycines $\mathrm{CP}$ propeptide, in which the prodomain product strongly inhibited a mature cathepsin L-like proteinase and other CPs of other related phytonematode species, but no effect was observed against insect digestive proteinases [27]. Besides, the procongopain chimeric peptide was also able to inhibit its cognate enzyme, congopain, but was unable to inhibit human cathepsins B and L. The authors suggest that procongopain propeptide is specific to protozoa enzymes, being unspecific to other kingdoms [16]. In order to shed some light over the specificity question, many authors tried to correlate the primary structure with its molecular specificity [25-29]. Nevertheless, this correlation was not elucidated.

\section{Conclusion}

In this report, a recombinant propeptide from an insect cysteine proteinase was investigated for its ability to inhibit the mature enzyme in order to be biotechnologically used as inhibitor target of specific proteinases. Our data showed that the product of $\mathrm{A}$. obtectus CP prodomain preferentially inhibited midgut CPs from Bruchidae family. Surprisingly, no inhibitory activity against other digestive CP proteinases from other coleopteran genus as R. dominica and A. grandis was found. Understanding the propeptide inhibitory mechanism and its specificity toward the digestive CPs from insect species could be useful for the development of molecular strategies for insect pest control tailored for the inhibition of specific target systems. In summary, this report proposes a different strategy to control bean bruchids by using a novel endogenous 
prodomain peptide. In the near future, this strategy could be used as a biotechnological tool, possibly reducing pest infestation and decreasing cop losses, offering several benefits to farmers and consumers.

\section{REFERENCES}

[1] Bezemer TM, Wagennaar R, Van Dam NM, Wäckers FL. Interactions between above- and belowground insect herbivores as mediated by the plant system. OIKOS 2003;101:555-62.

[2] Billington CJ, Mason P, Magny M-C, Mort JS. The slowbinding inhibition of cathepsin $\mathrm{K}$ by its propeptide. Biochem Biophys Res Commun 2000;276:924-9.

[3] Bode W, Engh R, Musil D, Thiele U, Huber R, Karshinov A, et al. The 2.0 A X-ray crystal structure of chicken egg white cystatin and its possible mode of interaction with cysteine proteinases. EMBO J 1988;7:2593-9.

[4] Carmona E, Dufour E, Plouffe C, Takebe S, Mason P, Mort JS, et al. Potency and selectivity of the cathepsin L propeptide as an inhibitor of cysteine proteases. Biochemistry 1996;35:8149-57.

[5] Cygler M, Mort JS. Proregion structure of members of the papain superfamily mode of inhibition of enzymatic activity. Biochimie 1997;79:645-52.

[6] Czaplewski C, Grzonka Z, Jaskólski M, Kasprzykowski F, Kozak M, Politowska E, et al. Binding modes of a new epoxysuccinyl-peptide inhibitor of cysteine proteases. Where and how do cysteine proteases express their selectivity? Biochim Biophys Acta 1999;1431:290-305.

[7] Dias SC, Franco OL, Magalhães CP, Oliveira-Neto OB, Laumann RA, Figueira ELZ, et al. Molecular cloning and expression of an alpha-amylase inhibitor from rye with a potential for controlling insect pests. Protein J 2005;24: 113-23.

[8] Godat E, Chowdhury S, Lecaille F, Belghazi M, Purisima EO, Lalmanach G. Inhibition of a cathepsin L-like cysteine proteinase by a chimeric propetide-derived inhibitor. Biochemistry 2005;44:10486-93.

[9] Grossi-de-Sa MF, Martins de Sa C, Harper F, Coux O, Akhayat O, Pal JK, et al. Cytolocalization of prosome as a function of differentiation. J Cell Sci 1988;89:151-65.

[10] Guay J, Falgueyret JP, Ducret A, Percival MD, Mancini JA. Potency and selectivity of inhibition of cathepsin K, L and S by their respective propeptides. Eur J Biochem 2000;267:6311-8.

[11] Hilder VA, Bolter D. Genetic engineering of crop plants for insect resistance - a critical review. Crop Prot 1999;18: 177-91.

[12] Jouanin L, Bonadé-Bottino M, Girard C, Morrot G, Giband M. Transgenic plants for insect resistance. Plant Sci 1998;131:1-11.

[13] Karrer KM, Peiffer SL, Ditomas ME. Two distinct gene subfamilies within the family of cysteine protease genes. Proc Natl Acad Sci USA 1993;90:3063-7.

[14] Kreusch S, Fehn M, Maubach G, Nissler K, Rommerskirch $\mathrm{W}$, Schilling $\mathrm{K}$, et al. An evolutionarily conserved tripartite tryptophan motif stabilizes the prodomains of cathepsin Llike cysteine proteases. Eur J Biochem 2000;267:2965-72.

[15] Laemmli UK. Cleavage of structural proteins during the assembly of the head of bacteriophage T4. Nature 1970;227:680-5.

[16] Lalmanach G, Lecaille F, Chagas JR, Authié E, Scharfstein J, Juliano MA, et al. Inhibition of trypanosomal cysteine proteinases by their propeptides. J Biol Chem 1998;273:25112-6.
[17] Lazure C. The peptidase zymogen proregions: nature's way of preventing undesired activation and proteolysis. Curr Pharm Design 2002;8:125-33.

[18] Lecaille F, Kaleta J, Bromme D. Human and parasitic papain-like cysteine proteases: their role in physiology and pathology and recent developments in inhibitor design. Chem Rev 2002;102:4459-88.

[19] Melo FR, Mello MO, Franco OL, Rigden DJ, Mello LV, Genú $\mathrm{AM}$, et al. Use of phage display to select novel cystatins specific for Acanthoscelides obtectus cysteine proteinases. Biochim Biophys Acta 2003;1651:146-52.

[20] Michaud D, Bernier-Vadnais N, Overney S, Yelle S. Constitutive forms during development of the Colorado potato beetle Leptinotarsa decemlineata Say (Coleoptera: Chrysomelidae). Insect Biochem Mol Biol 1995;25: 1041-8.

[21] Nchimbi-Msolla S, Misangu RN. Seasonal distribution of common bean (Phaseolus vulgaris L.) bruchid species in selected areas. In: Proceedings: Bean Seed Workshop; 2001. p. 12-4.

[22] Oppert B, Morgan TD, Hartzer K, Lenarcic B, Galesa F, Brzin $J$, et al. Effects of proteinase inhibitors on digestive proteinases and growth of the red flour beetle Tribolium castaneum Herbst (Coleoptera: Tenebrionidae). Comp Biochem Physiol C 2003;134:481-90.

[23] Park H, Kim SL, Hong KM, Kim MJ, Shin CH, Ryu JS, et al. Characterization and classification of five cysteine proteinases expressed by Paragonimus westermani adult worm. Exp Parasitol 2002;102:143-9.

[24] Rawlings ND, Barrett AJ. Families of cysteine peptidases. Methods Enzymol 1994;244:461-86.

[25] Roche L, Tort J, Dalton JP. The propeptide of Fasciola hepatica cathepsin L is a potent and selective inhibitor of the mature enzyme. Mol Biochem Parasitol 1999;98:271-7.

[26] Santamaría I, Velasco G, Pendás AM, Paz A, López-Otín C. Molecular cloning and structural and functional characterization of human cathepsin $\mathrm{F}$, a new cysteine proteinase of the papain family with a long propeptide domain. J Biol Chem 1999;274:13800-9.

[27] Silva FB, Batista JAN, Marra BM, Fragoso RR, Monteiro ACS, Figueira ELZ, et al. Prodomain peptide of HGCP-Iv cysteine proteinase inhibits nematode cysteine proteinases. Gen Mol Res 2004;3:342-55.

[28] Solomon M, Belenghi B, Delledone M, Menachen E, Levine A. The involvement of cysteine proteinase and proteinase inhibitor genes in the regulation of programmed cell death in plants. Plant Cell 1999;11:431-3.

[29] Taylor MA, Baker KC, Briggs GS, Connerton IF, Cummings NJ, Pratt KA, et al. Recombinant pro-regions from papain and papaya proteinase IV - are selective high affinity inhibitors of the mature papaya enzymes. Protein Eng 1995;8:59-62.

[30] Taylor MA, Lee MJ. Trypsin isolated from the midgut of the tobacco hornworm, Manduca sexta is inhibited by synthetic pro-peptides in vitro. Biochem Biophys Res Commun 1997;235:606-9.

[31] Terra WR, Cristofoletti PT. Midgut proteinases in three divergent species of Coleoptera. Comp Biochem Physiol 1996;113:725-30.

[32] Visal S, Taylor MJ, Michaud D. The proregion of papaya proteinase IV inhibits Colorado potato beetle digestive cysteine proteinases. FEBS Lett 1998;434:401-5.

[33] Shompole S, Jasmer DP. Cathepsin B-like cysteine proteases confer intestinal cysteine protease activity in Haemonchus contortus. J Biol Chem 2001;276:2928-34.

[34] Yamamoto Y, Kurata M, Watabe S, Murakami R, Takahashi SY. Novel cysteine proteinase inhibitors homologous to the proregions of cysteine proteinases. Curr Protein Pept Sci 2002;3:231-8. 